\title{
The Fine Structure of Hamann's Organ in Leptodirus hohenwarti, a Highly Specialized Cave Bathysciinae (Coleoptera, Catopidae)
}

\author{
by \\ Fiorenza ACCORDI* and Valerio SBORDONI****
}

\section{INTRODUCTION}

Particular sense organs are to be found in the 7th, 9th and 10th antennal segments of the Catopid beetles and of some other related families of Staphylinoidea. Because of their structural complexity and puzzling function, these structures have, in recent years, attracted the attention of a number of authors.

It seems of interest to trace an outline of studies so far conducted on these organs which promise a greater insight into both the phylogenetic relationship among some staphylinoid beetle families and the evolutionary patterns of Catopidae in adapting to the cave environment. The discovery and first description of these structures was ascribed to Jeannel (1911). However, careful reading of a paper by Hamann (1898) on sense receptors of some Bathysciinae convinced us of the importance of the studies by this author. Perhaps some of Jeannel's misunderstanding of Hamann's work stemmed from his way of numerating the antennal articles. In fact Hamann reported olfactory vesicles as occurring in the 2nd, 3rd and 5th antennal segments in Bathysciinae. This would appear to correspond to the actual location of the receptors, when counting the articles starting from the antennal tip. Jeannel $(1908,1911)$ was unaware of the sensory organs in the 9 th and 10th antennal articles and so was perhaps induced into rejecting Hamann's findings.

Hamann was able to describe the antennal receptors of Speophilus kiesenwetteri, Centhmonocharis freyeri and Leptodirus hohenwarti in some detail, in spite of the limitations of the light microscope. He even noted the spindle shape of the vesicle and periarticular gutter sensilla.

The afore-going facts would seem to suggest that this sensory structure, otherwise known as "vesicule olfactive", "antennal organ" or "antennal vesicle", be referred to in future as Hamann's organ, in honour of its discoverer. Jeannel (1911) reported on the vesicular organ in the 7 th article of the Bathysciinae. Unfortunately he gave a misleading description of the sensilla

* Institute of Zoology = University of Rome, Viale dell' Universita 32,00100 Roma, Italy.

** To whom reprint requests should be addressed. 
in the vesicle, in that he believed them to be hexagonal plaques, each perforated by a peg.

The first electron microscope study of Hamann's organ was performed by Baccetti and Sbordoni (1967). They investigated the morphology of the vesicles in two species of Bathysciinae with differing degrees of cave life specialization, i.e. in Bathysciotes khevenhülleri and Leptodirus hohenwarti. Even if detailed descriptions and micrographic illustrations were given during the 34th Congress of the Italian Union of Zoologists at Messina, only a short summary was published. The essential ultrastructure and innervation features of the two types of sensilla (described in the present paper as "cribrose-stick" and "cribrose-utricular"), located in the gutter and in the vesicles of the 7th, 9th and 10th antennal articles, were clearly reported. In addition, accounts of the morphology of Hamann's organ have already been given in various papers concerning both the taxonomy and evolution of Catopidae (Sbordoni, 1961 and 1963; Sbordoni and Cobolli-Sbordoni, 1973).

Later, Corbière-Tichané (1974) gave a thorough description with ample, high quality photographic documentation of the sensory organ in Speophyes lucidulus. Besides the two main types of sensilla, previously described by Baccetti and Sbordoni, Corbière-Tichané illustrated two additional types (starshaped and claviform pegs) located in the periarticular gutter.

Other recent papers describe or compare the structure of Hamann's organ in different taxa of the Catopid family (Corbière-Tichané, 1977; Peck, 1977). Peck, in particular, shows the peculiar morphology of the sensilla in the vesicles in Ptomaphagus to be quite different from those in Bathysciinae.

The object of this paper is to describe the structure of Hamann's organ in Leptodirus hohenwarti, in detail and with the aid of a Transmission Electron Microscope (TEM) and of a Scanning Electron Microscope (SEM), this species being a typical representative of ultraspecialized troglobitic Bathysciinae and subject of behaviour experiments in our laboratories.

The possible function and evolutionary patterns of this complex sense organ in Catopidae and related families are also discussed. Another paper (Lucarelli and Sbordoni, 1978) reports on experiments into the role of Hamann's organ in full detail.

As other authors have used different terms to indicate various parts of the organ, we have summarized the status of nomenclature (and synonymy) concerning Hamann's organ in Table 1.

\section{MATERIALS AND METHOD}

Specimens of Leptodirus hohenwarti were collected from the Noè cave, near Aurisina (Trieste) and reared in saturated atmosphere thermostatic chambers at $6^{\circ}$ in our laboratories. Details concerning ecology, methods of transferral and laboratory rearing of this species have been given by Sbordoni and Cobolli (1969).

Antennae were cut off from adult insects and carefully dissected to remove 
FINE STRUCTURE IN HAMANN ORGAN IN LEPTODIRUS

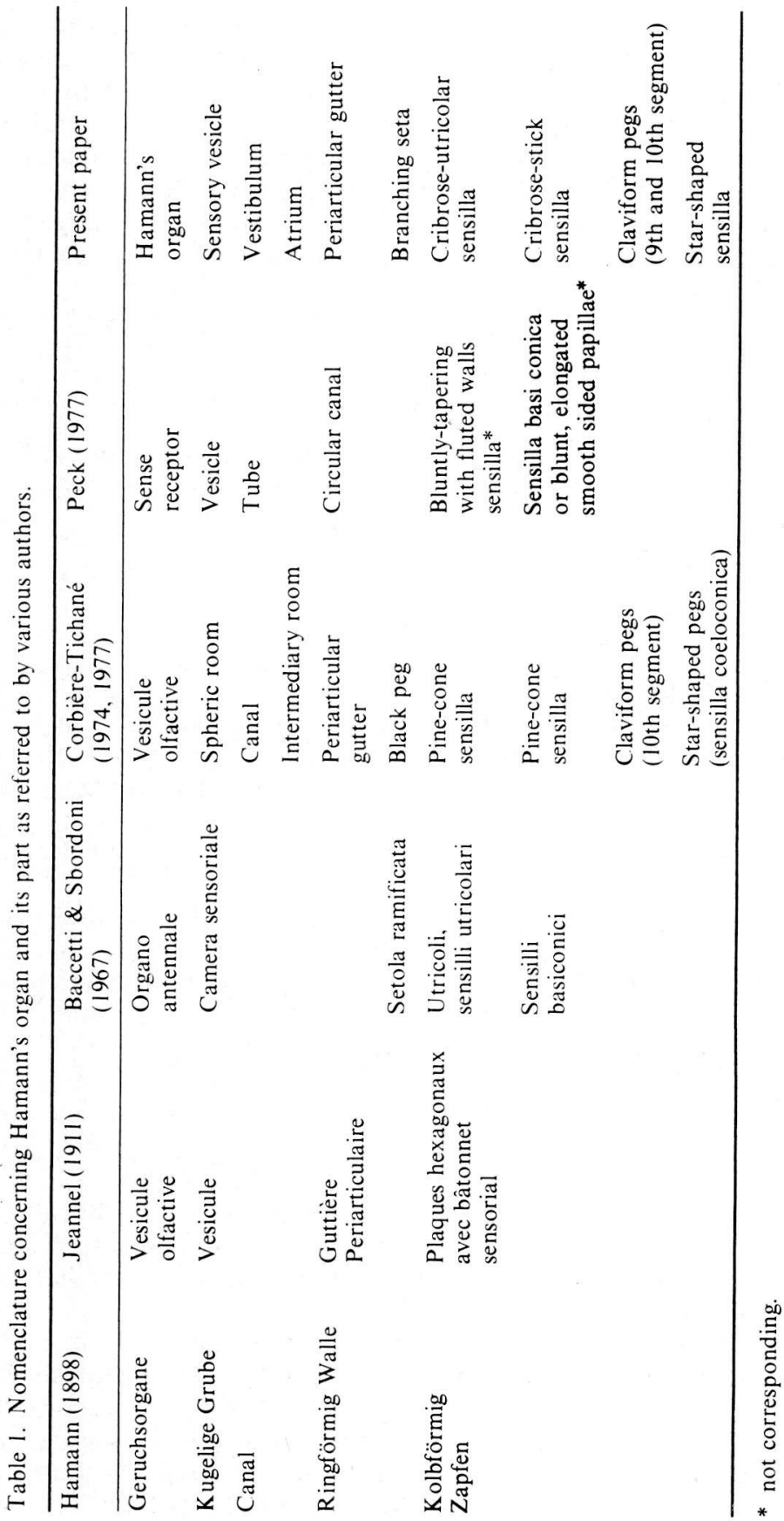


the external cuticular wall of the 7 th antennal article, in order to expose the organ, which was then fixed in $4 \%$ glutharaldehyde, in $70 \%$ alcohol or in Barber's fluid, and then transferred into a $0.1 \mathrm{M}$ cacodylate buffer.

Specimens for SEM observations were fixed in $1 \%$ osmium tetroxide, dehydrated in gradual ethanol series and in absolute acetone, then allowed to air dry and were subsequently stored in a dry atmosphere. Some organs were dissected before dehydrating, in order to observe the internal features. Antennae were mounted on standard mica squares and metal stubs, gold coated in vacuum and observed with a Cambridge Stereoscan Electron Microscope.

Specimens for TEM observations were fixed in $1 \%$ osmium tetroxide, dehydrated and embedded in Epon or Araldite. Thin sections, obtained with a LK B Ultrotome III, were stained with $10 \%$ uranyl acetate and lead cytrate and observed with a Siemens Elmiscope I A.

Observations under a light microscope were also performed and micrographs taken, mounting the antennae preserved in alcohol after clarifying them with clove oil or lactic acid.

\section{RESULTS}

7th article sensory organ:

The receptor organ occurring in the 7th antennal article of Leptodirus has a very complex structure. Its consists of the following parts (see table 1):

a) a sensory vesicle, deeply invaginated into the antennal segment and provided with a number of cribrose-utricular sensilla,

b) a vestibulum with the shape of a cylindrical neck flaring distally and bearing a long branching seta,

c) a periarticular gutter containing a ring of cribrose-stick and star-shaped sensilla.

After extracting the organ from the cuticular wall of the 7 th antennal article, the entire structure was examined in detail by SEM; its maximum length was found to be about $100 \mu$ and fully covered by a cuticular lining. The sensory vesicle was seen to be nearly spherical in shape, rather compressed laterally, with a longitudinal diameter of $40 \mu$ and a thickness of $27 \mu$. Its external surface was seen to be perforated by almost 60 pores with an invaginated inside cuticular lining. An internal spongy structure was recognizable within the pores from which some filaments and stubs also emerged probably indicating stumps of nerve fibers. The cylindrical neck, about $14 \mu$ long, corresponding to the vestibulum, eccentrically connects the sensory vesicle to the medial side of the periarticular gutter.

Under TEM examination, the sensory vesicle appeared to be lined by a thick cuticular wall breaking off in correspondence with the previously described pores. From each pore a cribrous utricular sensillum penetrates into the internal cavity of the vesicle. The number of sensilla therefore appeared to correspond to the number of pores. The cribrose utricular sensilla were seen to be barely elongated with a length of $10-12 \mu$ and a breadth of 5-6 $\mu$. They were per- 


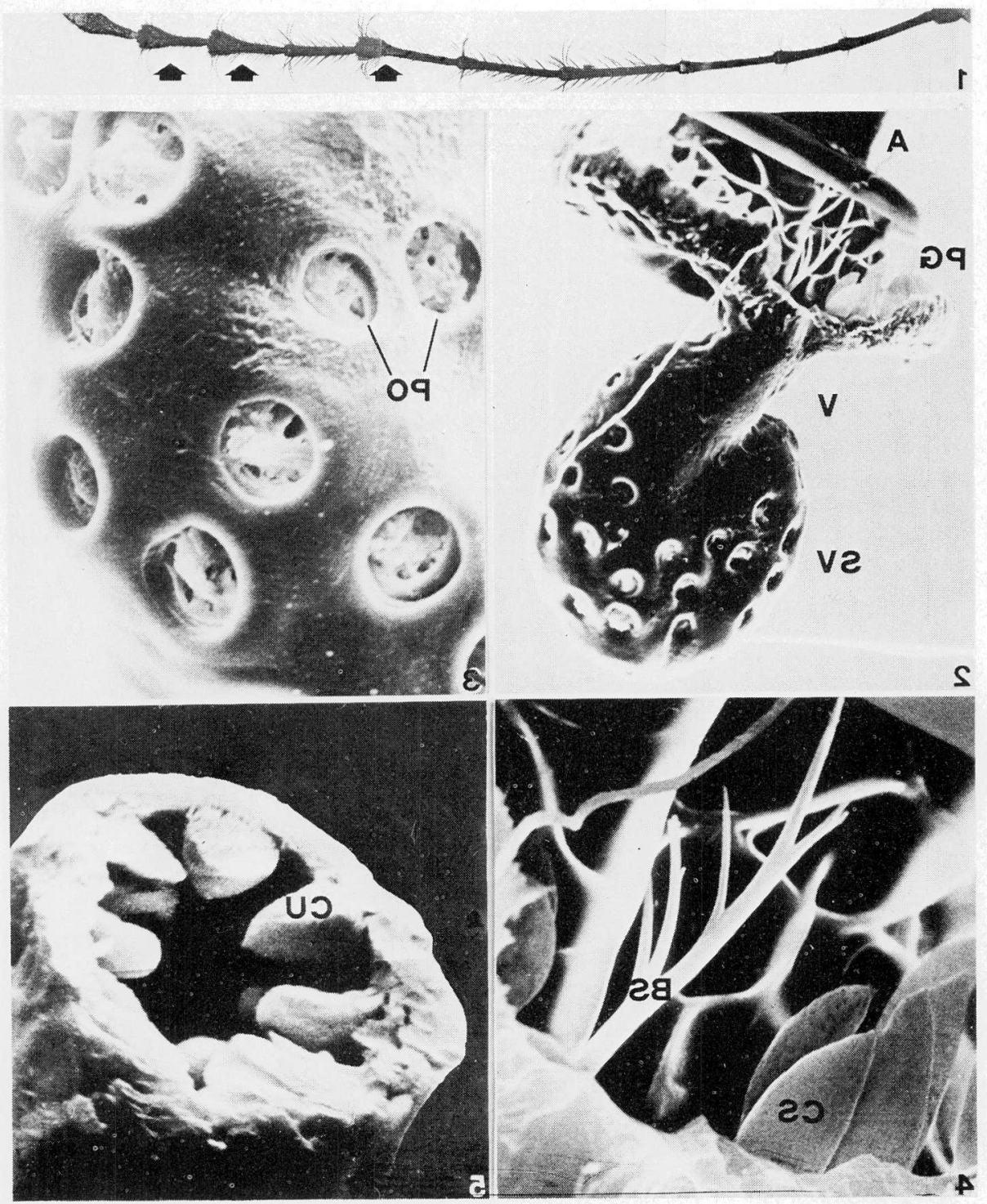

Fig. 1. Light micrograph of a whole antenna of Leptodirus hohenwarti, 7 th, 9 th and 10 th articles are indicated by arrows (x 42).

Fig. 2. The whole Hamann's organ of the 7th antennal article, as observed under SEM, A: 8th antennal segment. PG: periarticular gutter, V: vestibulum, SV: sensory vesicle (x 510).

Fig. 3. Sensory vesicle under SEM examination: detail of the external surface. Each pore (PO) corresponds to one internal cribrose-utricular sensillum (x 2250).

Fig. 4. Periarticular gutter of the 7 th antennal segment by SEM, detail of the branching seta (BS), CS: cribrose-stick sensilla (x 2050).

Fig. 5. Cross section of the sensory vesicle ( 7 th antennal segment) by SEM, showing cribroseutricular sensilla (CU) (x 1100). 

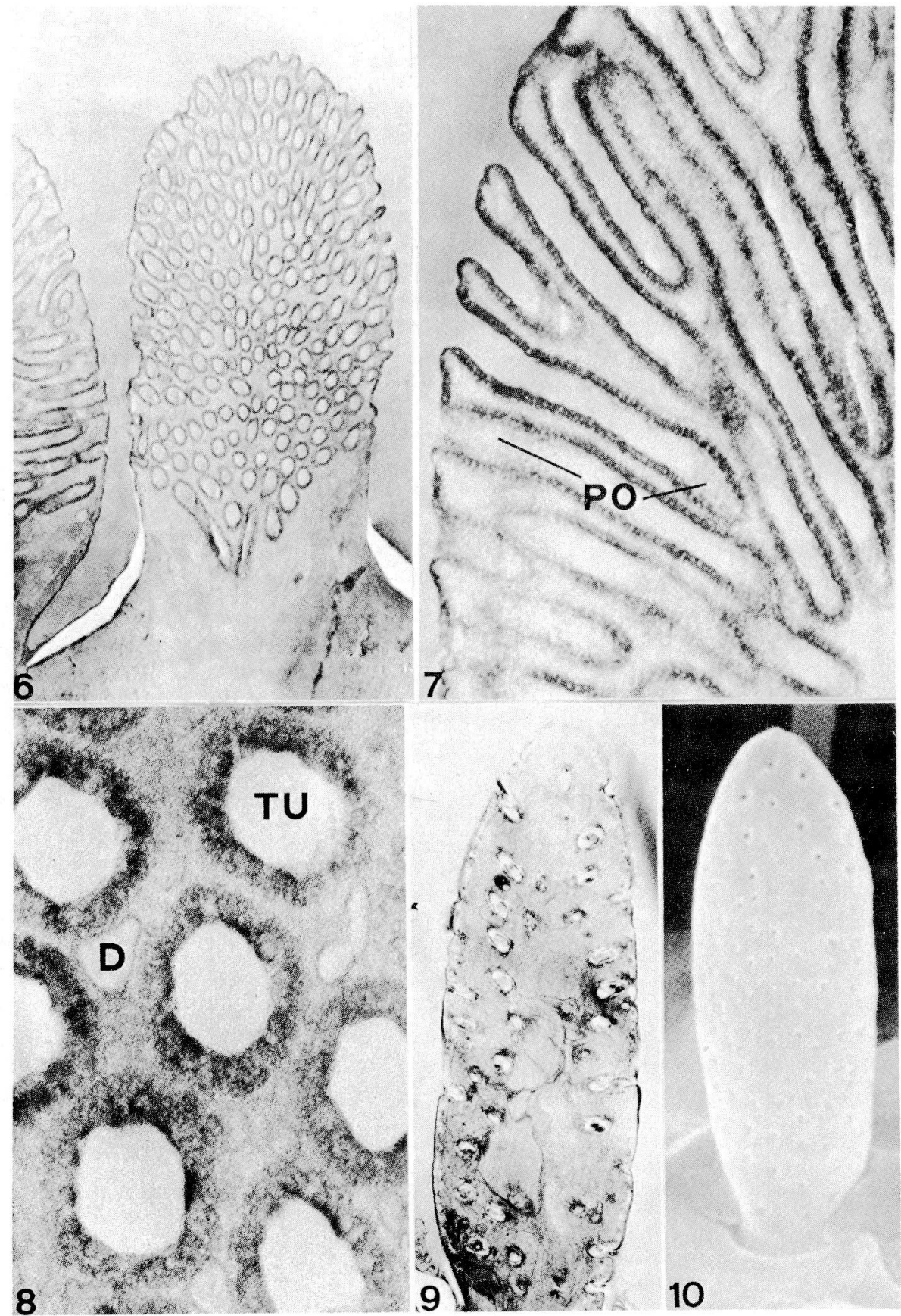
Fig. 6. Cribrose-utricular sensillum from 7 th article sensory vesicle, as seen under TEM in longitudinal section. Tubules are seen in transverse section (x 8300).

Fig. 7. Detail of a cribrose utricular sensillum. High magnification of tubules in longitudinal section allows to distinguish pores $(\mathrm{PO})$ in the cuticular lining $(\mathrm{x} 27,000)$.

Fig. 8. Detail of a cribrose utricular sensillum showing cross section of the tubules (TU). Dendritic membranes (D) are visible among them (x 89,650).

Fig. 9. Cribrose-stick sensillum from the 7 th article periarticular gutter in longitudinal section (x 8300).

Fig. 10. The same sensillum as observed under SEM (x 5800).

forated by a number of tubules rising up from the inner part of the sensillum and opening at the surface of it. The entire sensillum and the tubules were noted to be covered by a thin cuticle. High magnification of the tubules revealed a more complex structure of the lining which in fact appeared to be perforated by a number of small pores, which could be interpreted as evaginations of the cuticle. The diameter of each tubule was estimated to be $0.1-0.2 \mu$, its length varying according to position with a mean of $3.5 \mu$; the small pores were seen to have a diameter of about $150 \AA$. The lumen of the tubules appeared to be mainly empty. Membranes were seen to be widely distributed among the tubules and closely adhered to the small evaginations. We also found them at the base of the sensilla: these were the branches of the dendrite entering the sensory vesicle through the pores, as previously reported. Each cribrose utricular sensillum was seen to be innervated by a single neuron which assumed a lamellar structure before entering the vesicle.

The vestibulum was seen to be cylindrical in shape and elongating into an enlargement (atrium) giving on to the periarticular gutter. In the middle of the vestibulum internal wall, a long branching seta, with its ramifications, was seen to emerge from the periarticular gutter.

The periarticular gutter surrounds the base of the 8th antennal article. Through it the whole organ communicates with the external environment. Both SEM and light microscope examination showed an irregularly cristated floor, circumscribed by a prominent scalloped rim. A ring consisting of two types of sensilla was seen in the gutter. The cribrose-stick sensilla appeared to be more numerous, 30-40 having been counted. Being externally perforated, they were seen to resemble the previously described cribrose-utricular sensilla. When compared with the latter, however, they appeared to be thinner and more elongated ( $10 \mu$ long and $3 \mu$ thick). The pores were regularly distributed in 15-20 vertical lines and the tubules were seen to be shorter and larger. More diverse internal structures such as vacuoles and membranes also appeared to exist among the tubules.

The second type of sensilla occurring in the gutter corresponds to the starshaped pegs described by Corbière-Tichané in Speophyes. They were seen to have cylindrical base which became increasingly stellate towards the tip. From SEM examination the sensilla appeared to be similar to short trichoid sensilla basiconica with grooved surface tapering pronouncedly towards the tip. In this respect the sensilla would appear to be quite different from the interpretative diagrams of Corbière-Tichané. Star-shaped sensilla in Leptodirus were 
seen to be about twice as long as the previously described sensilla and only $10-15$ in number.

9th and 10th articles sensory organs:

Two additional sensory receptor organs occur in the 9th and 10th antennal segments. Each segment was seen to bear two rather invaginated vesicles inside. The vesicles were noted to be of different sizes, the medial one being deeper and longer than the lateral one and having a more developed vestibular part. They were seen to contain about 20 and 8 cribrose-stick sensilla respectively. In the former, the vestibulum was observed to exceed the vesicle in diameter. Branching setae emerged from the vesicles. These were seen to be characterized by a short apical brush.

Both the vesicles communicate with a periarticular gutter where cribrosestick sensilla are present together with some sensilla which we relate to the claviform pegs that Corbière-Tichané only founded in the 10th antennal article of Speophyes. In Leptodirus these sensilla were seen to vary both in length and shape, some of them being very long and slender with a peduncle up to three times shorter than the club. Close pores were noted to range throughout the club, but not to be present on the peduncle.

\section{DISCUSSION}

The fine structure of Hamann's organ in Leptodirus hohenwarti closely resembles that in other Bathysciinae species studied under the electron microscope (Baccetti and Sbordoni, 1967; Corbière-Tichané, 1974, 1977). Evidence drawn from light microscope observations on several species of Bathysciinae (Hamann, 1898; Jeannel, 1911; Sbordoni, 1971, and unpublished data; Corbière-Tichané, 1973) further supports the idea that this is a unique organ among insects and structurally uniform throughout the entire subfamily.

However, differences do exist among various sectiones, genera and species. The differences concern the number and complexity of the vesicles and the structure of the sensilla and appear to depend on the following factors:

1) the phyletic distance between taxa;

2) the degree of specialization to cave environment within a particular phyletic group.

A single sensory vesicle is present in the 7 th antennal article of all the Bathysciinae so far examined, although some aberrant individuals with complementary vesicles have been detected both in Leptodirus hohenwarti and in Speonomus lostiai (unpublished data). Conversely the 9th and 10th articles offer substantial differences in the number of vesicles. While most Bathysciinae have a single vesicle on each 9 th and 10th article, Leptodirus hohenwarti as

Fig. 11. The periarticular gutter of the 7th antennal article under SEM examination. Cribrosestick sensilla (CS), star-shaped sensilla (SS) and the branching seta (BS) are recognizable (x 900). 


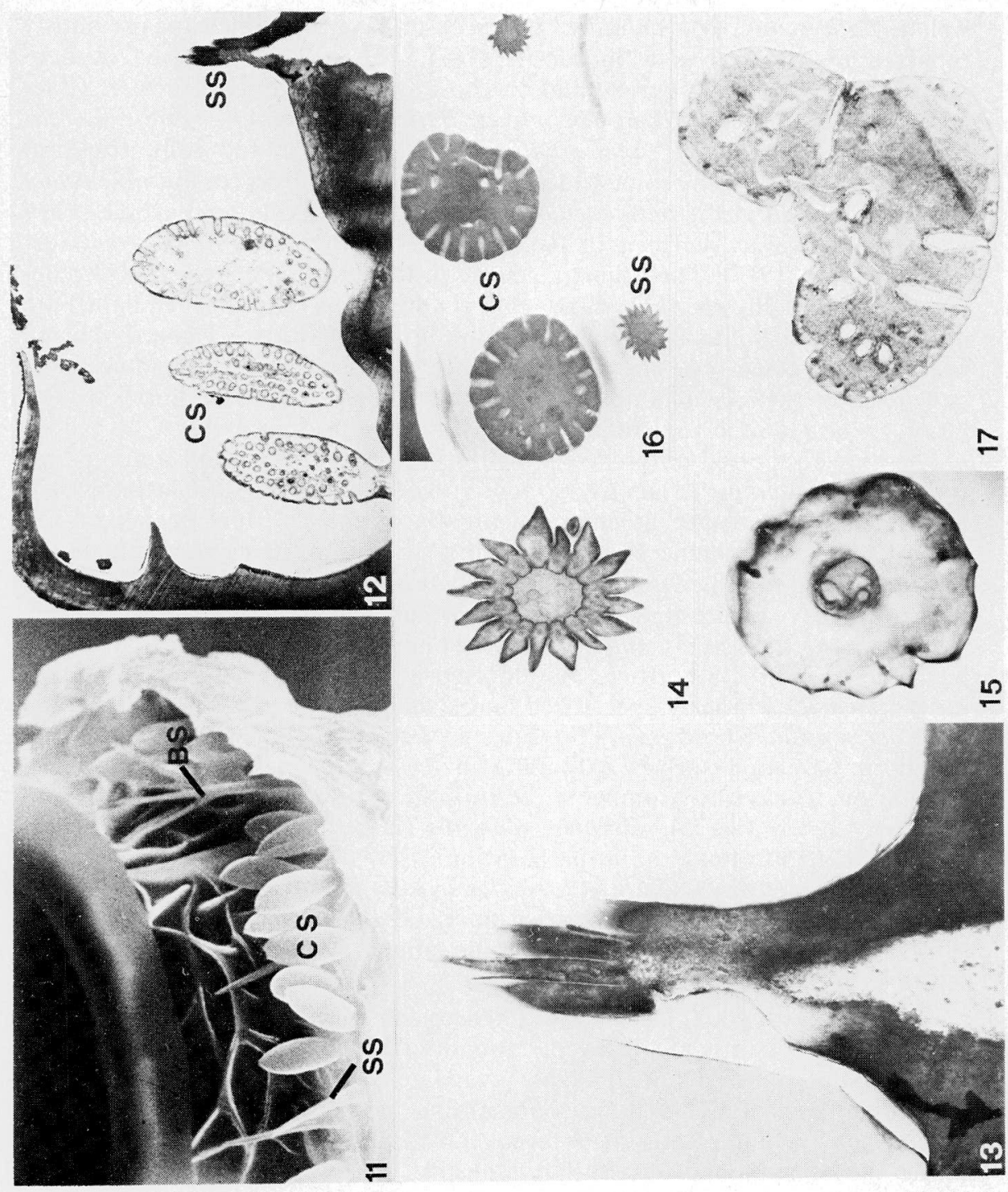

Fig. 12. Longitudinal section of cribrose-stick sensilla (CS) and star-shaped sensillum (SS) in the periarticular gutter of the 7 th article (x 2150).

Fig. 13. Star-shaped sensillum in longitudinal section (x 11,000).

Figs. 14 and 15. Two cross sections at different levels of the star-shaped sensillum. Dendrites are visible in the lumen $(x$ 16,250).

Fig. 16. A cross section of the periarticular gutter showing two cribrose-stick sensilla (CS) and two star-shaped sensilla (SS) (x 3900).

Fig. 17. Cross section of a cribrose-stick sensillum (x 9750). 
well as Bathysciotes khevenhülleri were seen to have two vesicles as previously reported by Baccetti and Sbordoni (1967). The sensilla observed in Leptodirus do not exactly correspond to those described in Bathysciotes (Baccetti and Sbordoni, 1967) or Speophyes, Bathysciola, Troglodromus, Isereus (Corbière-Tichané, 1977). The claviform pegs in the 9th and 10th articles of Leptodirus appear to be somewhat particular. In Speophyes comparable structures are located in the periarticular gutter of the 10th antennal article. They were not, however, detected in Bathysciola, Troglodromus or Isereus (Corbière-Tichané, 1977). The branching setae in the Leptodirus vesicles (also detected in the highly specialized Astagobius angustatus (unpublished data)) are not present in the other species where simple bristles (Corbière-Tichané's "black pegs") are reported. The star shaped sensilla also seem to present some shape and structure differences among the genera studied. SEM observations would, however, be required to actually prove said differences do exist.

The above reported differences which occur to various extents among Leptodirus, Bathysciotes, Astagobius, Speophyes, Troglodromus and Isereus could be related to the degree of phylogenetic relationships within these taxa. On the other hand, differences in number and structure of the cribrose utricular sensilla among the various species is clearly related to the degree of specialization to the cave environment. In fact, Leptodirus hohenwarti, the most specialized among the species studied, shows the highest number of sensilla (50-60) in the vesicle of the 7 th article. As reported in its original description, Ochridiola marinae, a poorly specialized, soil-dwelling species, only displays 6-8 utricular sensilla (Sbordoni, 1971). Intermediate numbers of sensilla have been found in unrelated species exhibiting increasing degrees of morphological adaptation to cave environment: Bathysciola derosasi (20 sensilla), Troglodromus bucheti (20-25), Oryotus schmidti (25-30), Astagobius angustatus (40-60) etc. (Sbordoni et al. in preparation).

Differences in the structure of utricular sensilla mainly relate to the number and the diameter of tubules. So, for instance, Leptodirus, compared with Speophyes, shows thinner and more numerous tubules. No difference has been detected in the size of the utricular sensilla.

More interesting and clear-cut differences emerge when Hamann's organ in Bathysciinae is compared with corresponding structures in other subfamilies of Catopidae (sensu Jeannel, 1936). Available data reported by Peck (1977) on Ptomaphagus (subfam. Eucatopinae) and by Corbière-Tichané (1977) on Choleva sp. (subfam. Catopinae) reveal considerable differences in the sensilla lining the sensory vesicles. In Ptomaphagus hollow, fluted, apparently unperforated sensilla occur. In Choleva the sensilla are neither perforated by tubules nor fluted, presenting only scattered pores directly connected with a dense dendritic network. These findings account for a strong evolutionary radiation in the Catopidae family, indicating clear-cut differences among the three reported subfamilies.

In spite of the structural diversities among sensilla, parallel evolution in connection with adaptation to cave life occurs in both Bathysciinae and in the Ptomaphagus genus. 
The function of Hamann's organ was previously supposed to be mainly olfactory (Jeannel, 1911; Baccetti and Sbordoni, 1967; Corbière-Tichané, 1977; Peck, 1977), although Argano et al. (1969) hypothesised a role in hygroreception for Bathysciinae. Difficulties in understanding the possible role of $\mathrm{Ha}$ mann's organ mainly stem from its widespread occurrence in species belonging to different families, and occupying remarkably diverse niches (from pholeophiles to cavernicoles) and having different behaviour patterns. However, the reported development in structural complexity as both Bathysciinae and Ptomaphagus become troglobitic, seems to indicate a strong dependence on some particular factor which characterizes the cave environment. Now, if olfaction be important as one of the senses involved in the orientation of beetles in caves an even greater olfactory efficiency would be expected to characterize surface beetles, such as some Ptomaphagus species, that largely depend on olfaction to find food. Evidence shows to the contrary, however, that the organ in the epigean species is invariably less complex.

Among other possible functions, hygroreception could be more directly involved in adapting to the cave environment. This role of Hamann's organ has been tested by comparing the humidity responses of both intact and antennectomized subjects in two species of Bathysciinae, Leptodirus hohenwarti and Bathysciola derosasi, under various alternative R.H. conditions (Lucarelli and Sbordoni, 1978). The results clearly show that important hygroreceptors are located in the 7th, 9th and 10th antennal articles. So, it is very likely that Hamann's organs be responsible for hygroreception. A structure in the process of evolving as a hygroreceptor would be expected to exhibit a progressive increase in air-contacting surfaces. Such a process does actually occur in Bathysciinae both through the increase in number of sensilla and through structural complication of each sensillum where the area of the invaginated cuticular surface has been seen to increase. A similar process also occurs in Ptomaphagus where the external cuticular surface of the sensillum has become fluted. The evolution in the utricular sensilla could be so hypothesised as being due to a progressive modification and deepening of the tubules in the cribrose-stick sensilla. Likewise, we could hypothesise that the fluted sensilla of Ptomaphagus derive from some trichoid, cristate sensilla, not unlike the starshaped ones. However, more research into the structure of Ptomaphagus fluted sensilla is called for.

Due to the high degree of structural complexity other functions of this organ apart from the hygroreception cannot be excluded. It is worthy noting that Hamann's organ, which appears to be one of the most complex receptor structure in insects is not particular to the Catopidae, as suggested by CorbièreTichané (1973) as it also appears in some related families of Staphilinoidea, such as Anisotomidae (Crowson, 1967), Liodidae (sensu stricto), Colonidae, Leptinidae (Sbordoni et al., in preparation). 


\title{
ACKNOWLEDGEMENTS
}

\begin{abstract}
We are indebted to Prof. Baccio Baccetti who collaborated with the senior author (V.S.) in previous research into the Hamann's organ. We thank also Marina Cobolli Sbordoni for her assistance and Franco Ventola for his technical help. Thanks are due also to the Institute of Geology, Rome University, for the use of the SEM.
\end{abstract}

\section{SUMMARY}

Hamann's organ in Leptodirus hohenwarti, a highly specialized cave Bathysciinae, has been studied under the TEM, SEM and light microscope. This receptor organ, located in the 7 th, 9 th and 10 th antennal articles and previously referred to as the "vesicule olfactive" and as the "antennal organ" or "antennal vesicle", reaches its highest degree of structural complexity in Leptodirus. This paper attempts to establish some degree of synonymy among the terms used by earlier authors in describing the various antennal parts and sensilla. Five types of sensilla to be found in the organ are described, namely cribrose-stick sensilla, cribrose-utricular sensilla, star-shaped sensilla, claviform sensilla and branching setae. Comparisons within Bathysciinae species and among the latter and other subfamilies of Catopidae reveal differences in the number of vesicles and in the number and structures of sensilla, these differences appear to depend on 1) the degree of phylogenetic relationships among taxa and 2) the degree of specialization to cave environment. The considerable complexity of Hamann's organ, unrivalled by other insects organs, apart from light receptors, suggests that it has a plurality of functions. Its hygroreceptor role, supported by recent experimental work, is discussed here.

\section{RIASSUNTO}

Viene studiata la morfologia e la fine struttura dell'organo di Hamann (precedentemente indicato come "vésicule olfactive" o organo antennale) nelle antenne di Leptodirus hohenwarti, un Coleottero Batiscino cavernicolo ultraspecializzato. Tra le specie di Catopidi finora studiate, L. hohenwarti raggiunge il massimo grado di complicazione strutturale dell'organo di Hamann. Vengono descritti e illustrati 5 tipi di sensilli presenti negli organi situati sul $7^{\circ}, 9^{\circ}$ e $10^{\circ}$ segmento dell' antenna (sensilli cribrosobastoncellari, cribroso-utricolari, a stella, claviformi e setole ramificate) e viene stabilita una sinonimia con i recettori corrispondenti precedentemente illustrati da vari autori. Vengono discusse le differenze nella struttura dell'organo di Hamann tra varie specie di Catopidi. Tali differenze risultano correlate in parte con il grado di affinità filogenetica e in parte con il grado di specializzazione per l'ambiente cavernicolo. Viene infine discusso, sulla base di recenti ricerche, il ruolo igrorecettivo dell'organo di Hamann che costituisce una delle strutture sensoriali più complesse finora studiate negli insetti.

\section{REFERENCES}

ARGANO, R., M. COBOLLI SBORDONI and V. SBORDONI, 1969. The humidity responses of troglobitic Bathysciinae (Coleoptera, Catopidae) at various degrees of specialization. 5. Int. Kongr. Speläologie Stuttgart 1969, Abh., München 4.

BACCETTI, B. and V. SBORDONI, 1967. Prime osservazioni ultrastrutturali sull'organo antennale dei Bathysciinae. Boll. Zool., 34: 84-85.

CORBIËRE-TICHANÉ, G., 1973. Étude comparative de la "vésicule olfactive" de l'antenne chez les Coléoptères cavernicoles de la famille des Catopidae. C.R. Acad. Sci., 277: 2049-2051.

CORBIĖRE-TICHANÉ, G., 1974. Fine structure of an antennal sensory organ ("vésicule olfactive") of Speophyes lucidulus Delar. (cave Coleoptera of the Bathysciinae subfamily). Tissue \& Cell, 6 (3): 535-550. 
CORBIĖRE-TICHANÉ, G., 1977. Étude comparative au microscope électronique de la "vésicule olfactive" des Catopidae cavernicoles (Coléoptères). Ann. Sc. Nat., Zoologie, Paris, (12) 19: 89-110.

CROWSON, R. A., 1967. The natural classification of the families of Coleoptera. Reprint by E. W. Classey Ltd., Hampton, England.

HAMANN, O., 1898. Mittheilungen zur Kenntnis der Höhlenfauna. Zool. Anzeiger, 21: 529-531.

JEANNEL, R., 1908. Biospeologica V. Coléoptères (première série). Arch. Zool. exp. et gén., Paris, (4) 8: 267-326.

JEANNEL, R., 1911. Biospeologica XIX. Revision des Bathysciinae (Coléoptères Silphides). Arch. Zool. exp. et gén., Paris, (5) 7: 1-641.

JEANNEL, R., 1936. Monographie des Catopidae. Mem. Mus. Nat. Hist. Nat., (N.S.) 1: 1-433.

LUCARELLI, M. and V. SBORDONI, 1978. Humidity responses and the role of Hamann's organ of cavernicolous Bathysciinae (Coleoptera Catopidae). Int. J. Speleol. 9: 167-177.

PECK, S. B., 1977. An unusual sense receptor in internal antennal vesicles of Ptomaphagus (Coleoptera: Leiodidae). Can. Ent., 109: 81-86.

SBORDONI, V., 1971. Ochridiola marinae: nuovo genere e nuova specie di Bathysciinae endogei della Macedonia (Coleoptera, Catopidae). Fragm. Entom., 8: 29-40.

SBORDONI, V., 1973. A new cave dwelling Ptomaphagus (Coleoptera Catopidae) from Tabasco, Mexico. In "Subterranean Fauna of Mexico", Parte II, Acc. Naz. Lincei, Quaderno N. 171: 363-367.

SBORDONI, V. and M. COBOLLI, 1969. Note sull'allevamento sperimentale degli animali cavernicoli in laboratorio. Arch. Zool. It., 54: 33-57.

SBORDONI, V. and M. COBOLLI SBORDONI, 1973. Aspetti ecologici ed evolutivi del popolamento di grotte temperate e tropicali: Osservazioni sul ciclo biologico di alcune specie di Ptomaphagus (Coleoptera Catopidae). Int. J. Speleol., 5: 337-347. 